\title{
OPTIMIZING THE REACTIVITY OF A RAW-MATERIAL MIXTURE FOR PORTLAND CLINKER FIRING
}

\author{
OPTIMIZIRANJE REAKTIVNOSTI MEŠANICE SUROVIN PRI \\ ŽGANJU PORTLAND KLINKERJA
}

\author{
Marcela Fridrichová, Dominik Gazdič, Karel Dvořák, Radek Magrla \\ Brno University of Technology, Faculty of Civil Engineering, Veveří 331/95, 60200 Brno, Czech Republic \\ magrla.r@fce.vutbr.cz
}

Prejem rokopisa - received: 2015-07-01; sprejem za objavo - accepted for publication: 2016-03-16

doi:10.17222/mit.2015.187

\begin{abstract}
On the basis of long-term chemical, mineralogical and granulometric analyses it was concluded that concrete recycled materials are usable for the production of Portland cement clinkers. However, they should be combined with high-calcium limestone, because even the finest undersize fraction has a relatively low $\mathrm{CaO}$ content, usually not exceeding $10 \%$ of mass fractions Furthermore, it was concluded that batching recycled materials with high-calcium limestone in a ratio of about 1:3 can produce Portland cement clinker of the same quality as common commercial clinker. However, there is an issue with the preparation of the cement clinker in the very low reactivity of the raw-material mixture containing high-calcium limestone and an increased content of silica in the concrete component. In order to improve the reactivity of the raw-material mixture modifications with fluxes for clinker production were proposed. An undersize fraction of recycled concrete of 0-8 mm and high-calcium limestone were used to prepare the raw-material mixtures. Gypsum, $\mathrm{CaSO}_{4} \cdot 2 \mathrm{H}_{2} \mathrm{O}$, fluorite, $\mathrm{CaF}_{2}$, and sodium fluorosilicate, $\mathrm{Na}_{2} \mathrm{SiF}_{6} \mathrm{were}$ chosen as suitable additives. The prepared samples of raw-material mixtures were assayed for reactivity during the cement clinker firing process using the kinetic method. After the evaluation of the obtained results, a sample modified with the most effective grinding aid was burned in an operation rotary kiln. The effectiveness of the modifications was evaluated based on the phase composition of the burned cement clinker and by determining the technological properties.

Keywords: Portland clinker, high-calcium limestone, concrete recycled materials, gypsum, fluorite, sodium fluorosilicate
\end{abstract}

Na osnovi dolgotrajnih kemijskih, mineraloških in granulometrijskih analiz je mogoče zaključiti, da so reciklirani betonski materiali uporabni za izdelavo Portland cementnih klinkerjev. Vendar pa morajo biti kombinirani z apnencem z visoko vsebnostjo kalcija, ker ima tudi najdrobnejša frakcija relativno majhno vsebnost CaO, običajno pod 10 masnih \%. Poleg tega je mogoče zaključiti, da so serije recikliranih materialov z apnencem z visoko vsebnostjo kalcija v razmerju okrog 1:3, primerne za izdelavo Portland cementnega klinkerja, enake kvalitete kot je običajen komercialni klinker. Vendar pa je vprašanje, kako pripraviti cementni klinker pri nizki reaktivnosti mešanice surovin, ki vsebuje apnenec z visoko vsebnostjo kalcija in povečano vsebnost kremena v betonski komponenti. Da bi izboljšali reaktivnost mešanice surovin za proizvodnjo klinkerja, so bile predlagane modifikacije mešanice s talili. Najdrobnejša frakcija recikliranega betona od $0-8 \mathrm{~mm}$ in apnenec z veliko vsebnostjo kalcija sta bili uporabljeni za pripravo mešanice surovin. Mavec, $\mathrm{CaSO}_{4} \cdot 2 \mathrm{H}_{2} \mathrm{O}$, fluorit, $\mathrm{CaF}_{2}$ in natrijev fluorosilikat, $\mathrm{Na}_{2} \mathrm{SiF}_{6}$ so bili izbrani kot primerni dodatki. Pripravljeni vzorci mešanice surovin so bili z uporabo kinetične metode preizkušeni na reaktivnost med postopkom žganja cementnega klinkerja. Po oceni dobljenih rezultatov je bil vzorec, modificiran $\mathrm{z}$ najbolj učinkovitim brušenjem, žgan v rotacijski peči. Učinkovitost modifikacije je bila ocenjena na osnovi sestave faz žganega cementnega klinkerja in $\mathrm{z}$ določitvijo tehnoloških lastnosti.

Ključne besede: Portland klinker, apnenec z veliko vsebnostjo kalcija, reciklirani betoni, mavec, fluorit, natrijev fluorosilikat

\section{INTRODUCTION}

The basic raw material used in the cement industry is limestone. It is a rock that together with dolomite constitutes four fifths of all the sediments on the Earth's surface. For this reason its deposits may appear virtually inexhaustible. In spite of this, the overview of limestone mining in the second half of the $20^{\text {th }}$ century alone indicates that these large industrially-useable deposits are soon to shrink substantially with the current accelerating rate of mining. However, seeing as modern society produces a large amount of waste, such as FBC ashes and demolition waste, the possibility arises to process these as secondary raw-material resources for the production of building materials. As far as demolition waste is concerned, they are used mainly in the production of recycled materials that are well-established today as secondary aggregate. Only their finest, undersize fraction, typically from $0 \mathrm{~mm}$ to $8 \mathrm{~mm}$, does not find sufficient use. It is this finest fraction that contains the highest content of the original cement mortar whose chemical composition can approach that of raw materials for clinker burning. Based on long-term, chemical-mineralogical analyses at our institute, the conclusion was reached that the recycled materials are applicable in the burning of Portland clinkers. However, they must be combined with high-calcium limestone. Based on laboratory and pilot plant burning in a model rotary kiln, the optimal batching ratio was determined at $1: 3$. This batching delivers Portland clinker of the same quality as common commercial clinker. Nevertheless, the issue with obtaining clinker in this way is in the very low reactivity of the raw-material mixture containing high-calcium limestone and increased silica content in 
M. FRIDRICHOVÁ et al.: OPTIMIZING THE REACTIVITY OF A RAW-MATERIAL MIXTURE FOR ...

the concrete component. For this reason it is necessary to address the improvement of reactivity of a mixture designed this way. ${ }^{1-4}$

One option is to use fluxes or mineralizers. These substances have the capacity to intensify the rate of clinker formation and have positive effects on the properties of the clinker. ${ }^{5,6}$ Fluorides, sulfates, carbonates, chlorides, alkaline and metal oxides or various combinations have been widely studies and their favorable effect on the rate of clinkerization was reported. ${ }^{7-12}$

\section{METHODOLOGY}

The recycled material was made with recycled concrete of the undersize fraction of $0-8 \mathrm{~mm}$ and high-calcium limestone; their chemical analysis is in Table $\mathbf{1 .}$ The undersize fraction of recycled concrete was sorted in a ball mill $15 \mathrm{w} / \%$ remainder on a $0.09 \mathrm{~mm}$ screen. The high-calcium limestone was sorted in a similar way. Both the basic raw materials were then batched at the ratio recycled concrete : high-calcium limestone $1: 3$; this ratio was previously determined to be optimal. After batching and thorough homogenisation of both raw materials, ca. $100 \mathrm{~g}$ samples of recycled materials were prepared, modified by the chosen additives; i.e. gypsum, dosed at concentration of 1,2 , and $3 w / \%$, fluorite, tested at concentrations of $(0.5,1,1.5$ and 2$) w / \%$, and sodium fluorosilicate dosed at $(0.1,0.5$ and 1$) w / \%$. The prepared samples were then tested for reactivity during clinker firing using the kinetic method. The effectiveness of the modifications was determined on the basis of the phase composition of the clinker.

Table 1: Chemical composition of input components

Tabela 1: Kemijska sestava vhodnih sestavin

\begin{tabular}{|c|c|c|}
\hline \multirow{2}{*}{ Component } & \multicolumn{2}{|c|}{ Component content (\%) } \\
\cline { 2 - 3 } & $\begin{array}{c}\text { Recycled concrete } \\
0-8 \mathrm{~mm}\end{array}$ & Limestone \\
\hline $\mathrm{SiO}_{2}$ & 63.29 & 1.02 \\
\hline $\mathrm{TiO}_{2}$ & 0.38 & 0.05 \\
\hline $\mathrm{Al}_{2} \mathrm{O}_{3}$ & 9.87 & 0.57 \\
\hline $\mathrm{Fe}_{2} \mathrm{O}_{3}$ & 2.59 & 0.20 \\
\hline $\mathrm{MnO}$ & 0.07 & 0.01 \\
\hline $\mathrm{MgO}$ & 1.56 & 0.34 \\
\hline $\mathrm{CaO}$ & 9.39 & 54.70 \\
\hline $\mathrm{Na}_{2} \mathrm{O}$ & 1,72 & 0.01 \\
\hline $\mathrm{K}_{2} \mathrm{O}$ & 3.38 & 0.13 \\
\hline loss on ignition & 7.39 & 42.99 \\
\hline $\mathrm{SO}_{3}$ & 0.43 & 0.05 \\
\hline $\mathrm{Total}^{2}$ & 100.07 & 100.07 \\
\hline
\end{tabular}

After the reactivity had been evaluated the clinker was burned in a laboratory model rotary kiln in an amount of $5 \mathrm{~kg}$ from the raw material of the highest reached reactivity. After burning, the clinker was put to phase analysis by means of microscopy point integration and X-ray diffraction analysis. Then it was sorted together with $5 \mathrm{w} / \%$ gypsum in a ball mill into cement at a specific surface of $375 \mathrm{~m}^{2} \cdot \mathrm{kg}^{-1}$. The cement thus produced was tested for basic technological properties, i.e. granulometry, initial and final setting time and compressive and flexural strengths.

\section{REACTIVITY DETERMINATION}

The kinetic method of determining raw-material reactivity permits a separated evaluation of the influence of mineral resources and the influence of the means of raw-material preparation on the rate of clinker creation in the clinkering zone of the rotary kiln. The basis of the kinetic method is isothermal burning of the clinker at $1430{ }^{\circ} \mathrm{C}$ and its quantitative phase analysis by means of microscopy. Based on this analysis the rate constant $K$ of the reaction producing alite $\left(\mathrm{C}+\mathrm{C}_{2} \mathrm{~S}=\mathrm{C}_{3} \mathrm{~S}\right)$ is calculated from the kinetic Equation (1):

$$
K \cdot t=[1-\sqrt[3]{ }(1-\alpha)]^{2}
$$

where:

$\alpha$.... conversion level $\mathrm{CaO}$ to $\mathrm{C}_{3} \mathrm{~S}$

$t$..... time of isothermal burning

$K$.... rate constant

For the reactivity of raw material $R_{m}$ it follows Equation (2):

$$
R_{m}=K / K_{s}
$$

where: $K_{s} \ldots$. rate constant of comparative raw material.

The reactivity of the raw material $R_{\mathrm{m}}$ thus expressed constitutes the relative rate of isothermal formation of clinker from the raw material at a medium temperature in the clinkering zone of a rotary kiln. It includes the influence of all reactivity factors, which divided into uninfluenced factors of the raw resource (mineralogical composition and microstructure, the content of secondary oxides, etc.) and influenced factors of the raw-material preparation (composition, granulometry, homogeneity). The effect of the uninfluenced factors on reactivity can be determined during the standardization of the influenced factors, i.e., the preparation of raw materials with the same chemical and granulometric compositions. Because the practical implementation of this process is very difficult, it is carried out by calculation based on a knowledge of the mechanism and the kinetics of clinker production. In doing so, the results of the phase analysis of the determination $R_{\mathrm{m}}$ are used, supplemented by a screen analysis of the raw material. Thus, the following applies for the reactivity of the raw-material resource:

$$
R_{z}=k / k_{s}
$$

where:

$k$.... rate constant of raw the material with standardized parameters of preparation

$k_{s}$..... rate constant of comparative raw material with standardized parameters of preparation 
The results of the determination of the phase composition and reactivity are shown in Table $\mathbf{2}$, Table $\mathbf{3}$ and Table 4 for samples of the raw material with the individual modification additives. Besides these there are values determined for the reference sample of the raw material without additives.

Table 2: Raw material with added gypsum

Tabela 2: Surovina z dodatkom mavca

\begin{tabular}{|c|c|c|c|c|}
\hline \multirow{2}{*}{$\begin{array}{c}\text { Raw } \\
\text { material }\end{array}$} & \multicolumn{4}{|c|}{ Content of phase $(w / \%)$} \\
\hline & $\begin{array}{c}\text { Reference } \\
\text { sample }\end{array}$ & $\begin{array}{c}1 \% \\
\text { gypsum }\end{array}$ & $\begin{array}{c}2 \% \\
\text { gypsum }\end{array}$ & $\begin{array}{c}3 \% \\
\text { gypsum }\end{array}$ \\
\hline $\mathrm{C}_{3} \mathrm{~S}$ & 25.6 & 25.0 & 21.5 & 19.5 \\
\hline $\mathrm{C}_{2} \mathrm{~S}$ & 48.7 & 49.1 & 51.8 & 53.8 \\
\hline MH & 17.2 & 16.6 & 17.4 & 16.9 \\
\hline $\mathrm{C}_{\text {free }}$ & 8.5 & 9.3 & 9.2 & 9.8 \\
\hline pore & 35.6 & 37.5 & 37.8 & 38.0 \\
\hline $\mathrm{C}_{3} \mathrm{~S}_{\mathrm{rov}}$ & 61.5 & 64.2 & 60.4 & 60.8 \\
\hline \multirow[t]{2}{*}{$\mathrm{C}_{2} \mathrm{~S}_{\mathrm{rov}}$} & 21.3 & 19.2 & 22.4 & 22.3 \\
\hline & \multicolumn{4}{|c|}{ Reactivity } \\
\hline$R_{\mathrm{m}}$ & 0.18 & 0.15 & 0.12 & 0.10 \\
\hline$R_{\mathrm{z}}$ & 0.25 & 0.23 & 0.18 & 0.14 \\
\hline
\end{tabular}

Table 3: Raw material with added $\mathrm{CaF}_{2}$

Tabela 3: Surovina $\mathrm{z}$ dodatkom $\mathrm{CaF}_{2}$

\begin{tabular}{|c|c|c|c|c|c|}
\hline \multirow{2}{*}{$\begin{array}{c}\text { Raw } \\
\text { material }\end{array}$} & \multicolumn{5}{|c|}{ Content of phase $(w / \%)$} \\
\hline & $\begin{array}{c}\text { Reference } \\
\text { sample }\end{array}$ & $\begin{array}{l}0.5 \% \\
\mathrm{CaF}_{2}\end{array}$ & $\begin{array}{l}1 \% \\
\mathrm{CaF}_{2}\end{array}$ & $\begin{array}{r}1.5 \% \\
\mathrm{CaF}_{2}\end{array}$ & $\begin{array}{l}2 \% \\
\mathrm{CaF}_{2}\end{array}$ \\
\hline $\mathrm{C}_{3} \mathrm{~S}$ & 25.6 & 35.2 & 38.4 & 40.8 & 42.2 \\
\hline $\mathrm{C}_{2} \mathrm{~S}$ & 48.7 & 42.3 & 38.7 & 39.2 & 36.6 \\
\hline $\mathrm{MH}$ & 17.2 & 15.7 & 16.3 & 15.0 & 15.7 \\
\hline $\mathrm{C}_{\text {free }}$ & 8.5 & 6.8 & 6.6 & 5.0 & 5.5 \\
\hline pore & 35.6 & 35.4 & 38.3 & 36.1 & 39.0 \\
\hline $\mathrm{C}_{3} \mathrm{~S}_{\mathrm{rov}}$ & 61.5 & 63.9 & 66.2 & 61.9 & 65.4 \\
\hline \multirow[t]{2}{*}{$\mathrm{C}_{2} \mathrm{~S}_{\text {rov }}$} & 21.3 & 20.4 & 17.5 & 23.1 & 18.9 \\
\hline & \multicolumn{5}{|c|}{ Reactivity } \\
\hline$R_{\mathrm{m}}$ & 0.18 & 0.36 & 0.42 & 0.60 & 0.57 \\
\hline$R_{\mathrm{z}}$ & 0.25 & 0.55 & 0.63 & 0.97 & 0.90 \\
\hline
\end{tabular}

Table 4: Raw material with added $\mathrm{Na}_{2} \mathrm{SiF}_{6}$

Tabela 4: Surovina $z$ dodatkom $\mathrm{Na}_{2} \mathrm{SiF}_{6}$

\begin{tabular}{|c|c|c|c|c|}
\hline \multirow[b]{2}{*}{$\begin{array}{c}\text { Raw } \\
\text { material }\end{array}$} & \multicolumn{4}{|c|}{ Content of phase $(w / \%)$} \\
\hline & $\begin{array}{l}\text { Reference } \\
\text { sample }\end{array}$ & $\begin{array}{c}0.1 \% \\
\mathrm{Na}_{2} \mathrm{SiF}_{6}\end{array}$ & $\begin{array}{c}0.5 \% \\
\mathrm{Na}_{2} \mathrm{SiF}_{6}\end{array}$ & $\begin{array}{c}1 \% \\
\mathrm{Na}_{2} \mathrm{SiF}_{6}\end{array}$ \\
\hline $\mathrm{C}_{3} \mathrm{~S}$ & 25.6 & 30.9 & 36.5 & 40.2 \\
\hline $\mathrm{C}_{2} \mathrm{~S}$ & 48.7 & 45.3 & 42.4 & 38.1 \\
\hline MH & 17.2 & 16.9 & 16.5 & 16.3 \\
\hline $\mathrm{C}_{\text {free }}$ & 8.5 & 6.9 & 4.6 & 5.4 \\
\hline pore & 35.6 & 34.3 & 36.8 & 39.0 \\
\hline $\mathrm{C}_{3} \mathrm{~S}_{\mathrm{rov}}$ & 61.5 & 60.0 & 55.9 & 63.0 \\
\hline \multirow[t]{2}{*}{$\mathrm{C}_{2} \mathrm{~S}_{\mathrm{rov}}$} & 21.3 & 23.1 & 27.6 & 20.7 \\
\hline & \multicolumn{4}{|c|}{ Reactivity } \\
\hline$R_{\mathrm{m}}$ & 0.18 & 0.30 & 0.59 & 0.55 \\
\hline$R_{\mathrm{z}}$ & 0.25 & 0.43 & 0.89 & 0.85 \\
\hline
\end{tabular}

The results presented in the tables show that the reactivity of the raw material of the reference nonmodified sample is very low. The modification by gypsum influenced the reactivity of the raw material in the opposite way to what was assumed. Not only did it not increase the reactivity, it significantly reduced it at gypsum concentration of $2 \mathrm{w} / \%$. Furthermore, an increased $\mathrm{SO}_{3}$ content in the raw material caused an adverse increase of belite content at the expense of alite. On the other hand, fluorite had a very good influence on the reactivity of the raw material. With an increased content of this additive the values of the reactivity increased and the maximum was reached at $15 \mathrm{w} / \%$ dose. At the same time $\mathrm{CaF}_{2}$ had a positive influence on the formation of alite and as its content increased, so did the alite content in the clinker. $\mathrm{Na}_{2} \mathrm{SiF}_{6}$ also had a positive effect on the reactivity of the raw material. The maximum values of the effectiveness were between 0.5 and $1 \mathrm{w} / \%$, but the maximum values were a little lower than in the case of fluorite use. For a good reactivity of the raw material, the modification by fluorite with a concentration of $1.5 \mathrm{w} / \%$ was determined to be the optimum one and thus the raw material of this composition was used in further testing. It should be noted that this modification was very successful because reactivity afforded $R_{\mathrm{m}}=0.59$, respectively $R_{\mathrm{z}}=0.89$ is higher than, e.g., the reactivity of the raw material from the Mokra cement factory with its values $R_{\mathrm{m}}=0.52, R_{\mathrm{z}}=$ 0.51 .

\section{PILOT PLANT BURNING}

For pilot-plant burning the raw material with the additive $1.5 \mathrm{w} / \% \mathrm{CaF}_{2}$ was converted into the form of compacted pieces by means of its homogenization with $1 \%$ dextrin and water and subsequent processing using a plodder machine. The thus prepared and dried pieces were put in a model rotary kiln where they were burned at $1550{ }^{\circ} \mathrm{C}$. Cooling in the conditions of this burning was performed by sudden free fall of the clinker in the air out of the heating end of the kiln.

A qualitative representation of each phase of the burnt clinker was observed by means of X-ray diffraction analysis. A dominant content of alite was identified as well as the presence of belite was apparent only through diffraction $d_{\mathrm{hkl}}=0.2403 \mathrm{~nm}$, diffractive lines $\mathrm{C}_{3} \mathrm{~A}$ and
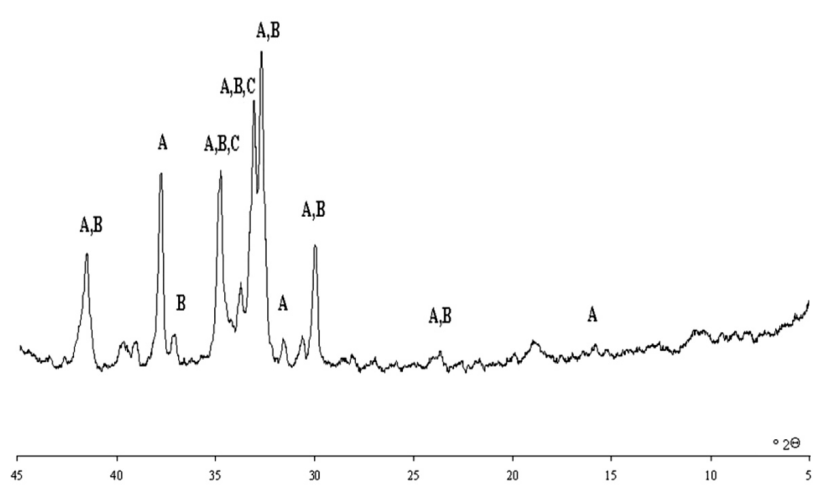

Figure 1: X-ray diffraction pattern of clinker: A - alite, B - belite, C $\mathrm{C}_{3} \mathrm{~A}$

Slika 1: Rentgenogram klinkerja: A - alit, B - belit, C - $\mathrm{C}_{3} \mathrm{~A}$ 
M. FRIDRICHOVÁ et al.: OPTIMIZING THE REACTIVITY OF A RAW-MATERIAL MIXTURE FOR ...

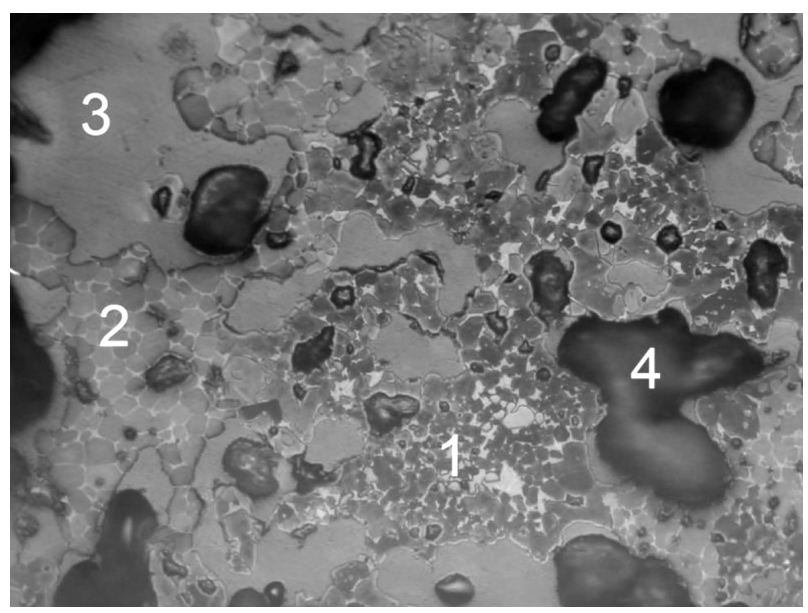

Figure 2: Microstructure of clinker: 1 - alite, 2 - belite, $3-\mathrm{C}_{3} \mathrm{~A}$ and $\mathrm{C}_{4} \mathrm{AF}, 4$ - pore

Slika 2: Mikrostruktura klinkerja; 1 - alit, 2 - belit, $3-\mathrm{C}_{3} \mathrm{~A}$ in $\mathrm{C}_{4} \mathrm{AF}$, 4 - pore

$\mathrm{C}_{4} \mathrm{AF}$ were featureless, see the $\mathrm{X}$-ray diffraction pattern in Figure 1.

The phase analysis carried out by means of microscopic point integration of the burnt sample identified it as a clinker with a dominant content of alite, a relatively high content of belite and $\mathrm{C}_{3} \mathrm{~A}$, and, on the other hand, a reduced amount brown millerite a slight remainder of free $\mathrm{CaO}$ (Figure 2). Alite formed hypautomorphic to automorphic crystals with a high degree of mutual coalescence. The average size of the alite crystals ranged from $25 \mu \mathrm{m}$ to $30 \mu \mathrm{m}$, while there were plentiful inclusions of alite in belite. Belite formed the usual oval agglomerates of grains with an average size of $15 \mu \mathrm{m}$ to $20 \mu \mathrm{m}$. Free $\mathrm{CaO}$ occurred only sporadically in the form of clusters of globular grains in alite areas. Quantitative phase composition of the burnt clinker is in Table 5.

Table 5: Phase composition of burnt clinker determined microscopically

Tabela 5: Sestava faz žganega klinkerja, določena z mikroskopom

\begin{tabular}{|c|c|}
\hline Phase & Content of phase $(w / \%)$ \\
\hline $\mathrm{C}_{3} \mathrm{~S}$ & 55.6 \\
\hline $\mathrm{C}_{2} \mathrm{~S}$ & 25.9 \\
\hline $\mathrm{C}_{3} \mathrm{~A}$ & 12.1 \\
\hline $\mathrm{C}_{4} \mathrm{AF}$ & 5.8 \\
\hline $\mathrm{CaO}_{\text {free }}$ & 0.6 \\
\hline Total & 100.0 \\
\hline
\end{tabular}

\section{TECHNOLOGICAL PROPERTIES OF THE BURNT CLINKER}

The pilot-plant burnt clinker was milled with 5 w/\% gypsum into cement with a specific surface of 375 $\mathrm{m}^{2} \mathrm{~kg}^{-1}$. Then it was tested for technological properties; the results together with the results of the properties of the reference cement are shown in Table 6. The reference cement was prepared using the same procedure as above with commercial clinker collected in the cement factory Mokra.

Table 6: Technological properties of alite cement

Tabela 6: Tehnološke lastnosti alit cementa

\begin{tabular}{|c|c|c|}
\hline Observed property & $\begin{array}{c}\text { Reference } \\
\text { sample }\end{array}$ & Alite cement \\
\hline Specific surface Blaine $\left(\mathrm{m}^{2} \mathrm{~kg}^{-1}\right)$ & 375 & 375 \\
\hline Water-cement ratio (\%) & 26.1 & 29.0 \\
\hline Initial setting time (h min) & $3: 05$ & $2: 05$ \\
\hline Final setting time (h min ) & $6: 45$ & $5: 00$ \\
\hline Compressive strength (MPa) & & \\
\hline $1 \mathrm{~d}$ & 23.2 & 28.6 \\
\hline $3 \mathrm{~d}$ & 45.5 & 54.8 \\
\hline $7 \mathrm{~d}$ & 46.6 & 63.8 \\
\hline $28 \mathrm{~d}$ & 56.1 & 76.5 \\
\hline Flexural strength $(\mathrm{MPa})$ & & \\
\hline $1 \mathrm{~d}$ & 6.6 & 8.5 \\
\hline $3 \mathrm{~d}$ & 9.1 & 13.6 \\
\hline $7 \mathrm{~d}$ & 10.6 & 15.9 \\
\hline $28 \mathrm{~d}$ & 11.6 & 16.9 \\
\hline
\end{tabular}

The results shown in the table indicate that at the same specific surface of the two compared cements, the reference cement showed a slightly lower value of water-cement ratio. The difference is probably connected with a slightly different phase composition of both clinkers. It is also evident that the tested cement, compared to the reference, has a shorter initial and setting time. This difference is related to the phase composition of the pilot-plant burnt clinker, respectively, with a relatively high proportion of $\mathrm{C}_{3} \mathrm{~A}$. The compressive strength values of the tested cement were after all the observed hydration times higher than the reference sample's strength on average by $30 \%$, and even the flexural strength was higher by $50 \%$. The main cause of this phenomenon can probably be considered to be the higher hydraulicity of the burnt clinker, given its modification by fluorite.

\section{CONCLUSIONS}

The insufficiency of preparation and pilot-plant production of Portland clinker based on recycled concrete and high-calcium limestone, which lay in the low reactivity of the raw material, has been removed by modifying with fluorite. At a dose of $1.5 w / \%$ of this additive in the raw material reactivity has improved so much that it even exceeded that of the normal raw material from the cement factory Mokra. It can be concluded that recycled concrete materials are utilizable for Portland cement burning in combination with high-calcium limestone. Because the resources of high-calcium limestone can also be found in existing waste materials, such as sugar factory sludge etc., their combination may represent not only the economic benefits, but particularly in the future, a contribution to the transition to non-waste technology 


\section{MATERIALI IN TEHNOLOGIJE/MATERIALS AND TECHNOLOGY (1967-2017) - 50 LET/50 YEARS}

\section{FRIDRICHOVÁ et al.: OPTIMIZING THE REACTIVITY OF A RAW-MATERIAL MIXTURE FOR ...}

too, and thus contribute to the protection of raw-material resources.

\section{Acknowledgment}

This work was financially supported by project number: GA14-32942S "Effect of fluidized bed ash on the thermodynamic stability of hydraulic binders" and project No. LO1408 "AdMaS UP - Advanced Materials, Structures and Technologies", supported by Ministry of Education, Youth and Sports under the "National Sustainability Programme I".

\section{REFERENCES}

${ }^{1}$ M. Fridrichová, J. Gemrich, Building recyclates as a partial material source for Portland clinker baking, Cement International, Verlag Bau + Technik GmbH, (2005)

${ }^{2}$ M. Fridrichová, J. Brauner, T. Stanìk, Recycled materials as a partial raw material for the production of Portland cement clinker, Ecology and new building materials and products, (2005), (in Czech)

${ }^{3}$ M. Fridrichová, D. Gazdič, K. Kulísek, Concrete recycled as subbase raw material for burning of belite clinker, Materiálové inženýrství, 1 (2009), 63-66, BUT Brno, (in Czech)

${ }^{4}$ M. Fridrichová, J. Brauner, P. Zlámal, J. Novák, Rohmehlmodifikation zum Brennen des Belitklinkers, IBAUSIL, 1 (2006),147-154, Finger Institut Bauhaus-Univ. Weimar

${ }^{5}$ I. Odler, Improving energy effiency in portland clinker manufacturing, Cement and Concrete Science and Technology, Vol. 1, Part. 1, ABI Books Private Limited, (1991), 174-200
${ }^{6} \mathrm{G}$. K. Moir, Improvements in the early strength properties of Portland cement, Philos. Trans. R. Soc. Lond., A 310 (1983), 127-138

${ }^{7}$ G. K. Moir, Mineralised high alite cements, World Cem 10 (1982), 374-382

${ }^{8}$ Larbi Kacimi, Angélique Simon-Masseron, Abdelhamid Ghomari, Zoubir Derriche, Influence of $\mathrm{NaF}, \mathrm{KF}$ and $\mathrm{CaF} 2$ addition on the clinker burning temperature and its properties, Comptes Rendus Chimie, 9 (2006) 1, 154-163, doi:10.1016/j.crci.2005.10.001.

${ }^{9}$ H. E. Borgholm, D. Herfort, S. Rasmusen, A new blended cement based on mineralised clinker, World Cement 8 (1995), 27-33

${ }^{10}$ A. Emanuelson, S. Hansen, E. Viggh, A comparative study of ordinary and mineralised Portland cement clinker from two different production units Part I: Composition and hydration of the clinkers, Cement and Concrete Research 33 (2003) 10, 1613-1621, doi:10.1016/S0008-8846(03)00115-7

${ }^{11}$ O. Dominguez, A. Torres-Castillo, L. M. Flores-Velez, R. Torres, Characterization using thermomechanical and differential thermal analysis of the sinterization of Portland clinker doped with $\mathrm{CaF}_{2}$, Materials Characterization, 61 (2010) 4, 459-466, doi:10.1016/ j.matchar.2010.02.002

${ }^{12}$ Joris Schoon, Anne Vergari, Klaartje De Buysser, Isabel Van Driessche, Nele De Belie, Fines extracted from porphyry and dolomitic limestone aggregates production: $\mathrm{MgO}$ as fluxing agent for a sustainable Portland clinker production, Construction and Building Materials, 43 (2013), 511-522, doi:10.1016/j.conbuildmat.2013. 02.046 